\title{
Household fuel use for cooking and heating in China: Results from the first Chinese Environmental Exposure-Related Human Activity Patterns Survey (CEERHAPS)
}

\author{
Xiaoli Duan ${ }^{\mathrm{a}, *}$, Yong Jiang ${ }^{\mathrm{b}}$, Beibei Wang ${ }^{\mathrm{a}}$, Xiuge Zhao ${ }^{\mathrm{a}, *}$, Guofeng Shen ${ }^{\mathrm{c}}$, Suzhen Cao ${ }^{\mathrm{d}}$, Nan Huang ${ }^{\mathrm{a}}$, \\ Yan Qian ${ }^{\mathrm{a}}$, Yiting Chen ${ }^{\mathrm{e}}$, Limin Wang ${ }^{\mathrm{b}}$ \\ a State Key Laboratory of Environmental Criteria and Risk Assessment, Chinese Research Academy of Environmental Sciences, Beijing 100012, China \\ ${ }^{\mathrm{b}}$ National Center for Chronic and Noncommunicable Disease Control and Prevention, Chinese Center for Disease Control and Prevention, Beijing 100021, China \\ ' Jiangsu Key Laboratory of Environmental Engineering, Jiangsu Academy of Environmental Sciences, Nanjing 210036, China \\ ${ }^{\mathrm{d}}$ Research Center for Eco-Environmental Sciences, Chinese Academy of Sciences, Beijing 100085, China \\ e Sichuan Academy of Environmental Sciences, Chengdu 610041, China
}

\section{H I G H L I G H T S}

- The first CEERHAPS survey obtained firsthand data on household fuel use in China.

- Solid fuel are widely used for cooking and heating, with large spatial variances.

- Statistically negative correlation between the income and solid fuel use fraction.

- Models for household fuel use estimation at national and provincial levels.

- The proportion of solid fuel use decreased during the last two decades.

\section{A R T I C L E I N F O}

\section{Article history:}

Received 20 January 2014

Received in revised form 16 September

2014

Accepted 20 September 2014

Available online 16 October 2014

\section{Keywords:}

CEERHAP

Cooking and heating

Household fuel use

Rural-urban difference

\begin{abstract}
A B S T R A C T
Household fuel-use (HFU) patterns are strongly associated with multiple effects, including air quality, human health, and regional climate change. This paper presents the results from the first Chinese Environmental Exposure-Related Human Activity Patterns Survey (CEERHAPS), carried out among 91,121 households located in 9108 villages, 636 towns, and 159 counties in 31 provinces. Face-to-face interviews were conducted with each participant to obtain information about the type of fuels used for cooking and heating. The main objectives of this paper were to investigate HFU for cooking and heating in China, to validate the World Health Organization (WHO) model, and to help inform local evaluation models. In China, gas and biomass fuels, the dominant energy fuels for cooking, are used by $44.8 \%$ and $32.1 \%$ of households, respectively. Approximately $34.1 \%$ of families have no household heating during the cold season, and $16.7 \%, 15.6 \%$ and $12.8 \%$ of households rely on coal, electricity, and biomass, respectively, for household heating when no central heating was available. The proportion of households using solid fuels has generally decreased during the last two decades. Considerable spatial variation was evident in the HFU patterns for both cooking and heating. The data revealed that the predominant fuel for cooking was biomass (47.6\%) in rural populations, whereas urban households were more likely to cook with gas (65.8\%). In terms of heating, coal (21.4\%) and biomass (19.0\%) were the main fuels used in rural households, while electricity (23.6\%) and coal (10.5\%) were more commonly used in urban areas. The overall HFU results for cooking from this study were comparable to those predicted using the WHO model. We also developed models at the provincial level to estimate HFU for cooking and heating in China; it is expected that the model, if confirmed by future studies, could be used for future research on household air pollution, domestic human exposure and burden of disease.
\end{abstract}

ㄷ 2014 Elsevier Ltd. All rights reserved.

\footnotetext{
* Corresponding authors. Tel.: +86 10 84921546; fax: +86 1084916422.

E-mail addresses: duan_jasmine@126.com (X. Duan), hkyzhaoxg@163.com (X. Zhao).
} 


\section{Introduction}

Household fuel use (HFU), which may include traditional solid fuels and/or newer, cleaner fuels, is of great interest, due to its strong association with multiple effects on local/regional air quality, climate change, and human health [1-3]. Because the majority of households in developing countries rely on solid fuels for daily cooking and heating needs, there are growing concerns over air pollution from solid fuel combustion and the associated health problems [4-7]. The most recent Global Burden of Disease study (2010) estimated that the exposure to smoke from household air pollution was responsible for approximately 3.5 million premature deaths globally, as well as other various health issues, such as cataracts and cardiovascular disease [8-10]. The percentage of the population that relies on solid fuels as their main energy source is one of the indices in the Millennium Development Goal indicators [11]. However, it is difficult to obtain wide-range representative data of various pollutants of interest.

Quantification of HFU (solid and non-solid fuels) can be obtained directly from household surveys, but few field surveys have been performed to date. Most previous surveys have mainly focused on fuel use over one specific year, making it difficult to identify changing trends. Recently, a multilevel model was developed to allow estimation of household solid fuel use (SFU) for cooking over the time period 1980-2010 [4]. The model has been used in risk analysis and disease burden studies. Because relatively few firsthand surveys have been conducted, empirical models of HFU have been essential to assess fuel consumption. However, it is widely accepted that field surveys are urgently required to validate the modeled results. Moreover, most surveys have not reported HFU for space heating. It has been recognized that large amounts of fuel are consumed for household heating during the cold season in most developing countries, and this kind of fuel consumption leads to serious indoor and outdoor pollution [12-15].

In China, fuels are widely consumed by an enormous population for household cooking and heating. Various types of fuels are used in practice, and HFU patterns vary dramatically between provinces and rural and urban areas. Moreover, HFU patterns may have changed dramatically over the past thirty years with accelerated socioeconomic development and urbanization. Unfortunately, the data related to HFU in China are very limited, and most available datasets are more than ten years old, so they cannot be used for realistic estimations of HFU patterns in China today. During 2012, the first Chinese Environmental Exposure-Related Human Activity Patterns Survey (CEERHAPS) was conducted by the Chinese Research Academy of Environmental Sciences and the Chinese Center of Disease Control. One of its goals was to collect data about HFU patterns, and these data are discussed in this paper.

In this study, we report the HFU patterns among urban and rural households in the different provinces in China, and explore possible influencing factors such as economic level, ambient temperature, and relatively humidity. It is expected that data about HFU for cooking can be used to some extent to validate previous estimations based on the WHO multilevel model, and the data on HFU for heating can help meet the research gap on SFU in the WHO database. Moreover, the provincial evaluation model developed in this study could be used in future domestic comprehensive risk analyses and burden of disease studies or to develop HFU-related policy.

\section{Methods}

\subsection{Sampling}

This HFU study was part of the first CEERHAPS. The HFU portion of the survey used a multi-stage cluster random sampling method, with economic situation and rural/urban status as stratified factors. The subjects in this portion of the survey included $91,527 \mathrm{vol}-$ unteers/households, located in 9108 villages, 636 towns, and 159 counties in 31 provinces (see Table 1). The results for each household were weighted in terms of sampling weight, no-response weight, and post-stratification weight.

\subsection{Survey}

Questionnaires were completed during face-to-face interviews with household participants to determine the cooking and heating use in individual households: type of fuel used for cooking and heating, heating duration, ventilation during cooking, and cooking location (e.g., whether or not the household had a separate kitchen).

Respondents selected from a list of cooking and heating fuels, including biomass, coal, gas, electricity/solar, and other. They also selected from a list of heating methods, including central heating (heating by piped water/steam transported from a remote boiler to each individual household), individual heating (heating by piped water/steam transported from a self-boiler in a separate room), space heating using coal, space heating using biomass, electricity, other, and no heating.

\subsection{Data analysis and $\mathrm{QA} / \mathrm{AC}$}

Statistical analysis was completed using the SAS software. All results were weighted and adjusted as follows: first, the obtained data were weighted using factors calculated from the probabilities for adults in the household, resident groups in the village/community, village/community numbers in the town, and towns in the investigated site; the weighted results were then adjusted using post-stratification weight analysis to normalize the population distributions of gender and age in our results with those in the 6th China National Census. A significance level of 0.05 was used for correlation analyses.

The exchange of subjects in the sampling roll with other subjects was strictly monitored; less than a $5 \%$ exchange rate was allowed for each field site. To ensure uniformity, all surveyors were trained, tested, and deemed qualified, in their understanding of the questionnaire content and possible responses. Parallel questionnaires were performed among 5\% of the participants. The subject response was $95 \%$ and the recovery rate of valid questionnaires was $99.6 \%$. Ultimately, 91,121 households located in 9108 villages, 636 towns, and 159 counties were used in the analysis.

\section{Results and discussion}

\subsection{HFU for cooking and temporal-spatial distribution}

Our national field survey for China estimated that in 2011, $44.8 \%, 32.1 \%, 11.7 \%$, and $11.3 \%$ of Chinese households relied on gas, biomass, solar/electricity, and coal for cooking, respectively. Household income, fuel accessibility and cooking habits typically vary. Urban residents use clean fuels such as gas more frequently than rural residents, a large population that uses traditional biomass and coal (Fig. 1), leading to distinct HFU patterns between urban and rural areas.

In rural households, solid fuels (mainly biomass at $47.6 \%$ and coal at $13.5 \%$ ) were the predominant fuel used for daily cooking, while urban households were more likely to use cleaner fuels such as gas (65.8\%) and solar/electricity (13.6\%) (Fig. 2). Although coal has been banned in most urban areas, a large number of urban households were still found to use coal and other traditional solid fuels for cooking (20.3\%, equal to approximately 144.5 million 


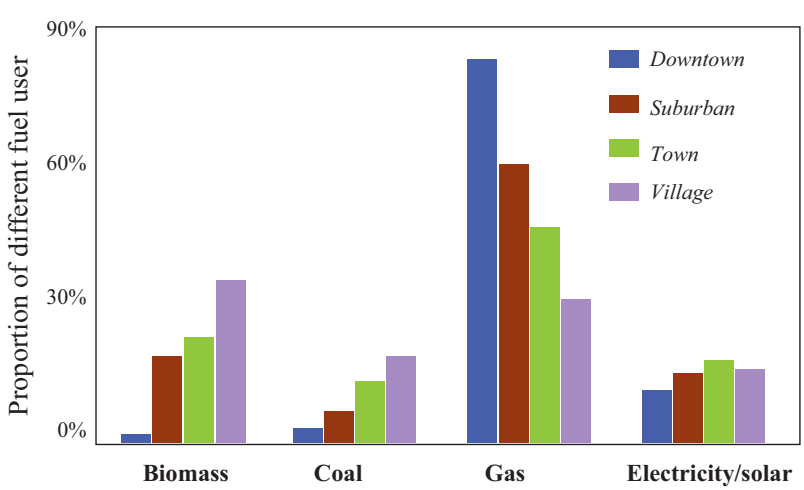

Fig. 1. Comparison of fuels used in Chinese households located in the downtown, suburban, town and rural village. Fuels here are classified into four groups of biomass (firewood and crop straw), coal, gas and others like electricity and solar energy.

people). Recently, a study based on a national-scale multilevel model [4] estimated that in $2010,46 \%$ of Chinese households using solid fuels for cooking (33-59\% with a 95\% confidence interval), slightly higher than our estimate of $43.3 \%$. Taking into account the relatively large variations and uncertainties in both studies (e.g., the different methodologies used and targeted years), these results are generally comparable. Further, the results from our extensive field survey may validate, to some extent, the WHO dataset based on the national-scale multilevel models.

The WHO information on HFU for cooking in China is available for 1991 to 2006, which provided an opportunity to investigate the historical change in HFU for cooking in China. Fig. 3 shows the temporal change in HFU for cooking in urban and rural China over the last two decades. These data are also listed in detail in Table S1; it is obvious that the patterns of HFU for cooking have been changing in China over the last two decades. In general, non-SFU in China has markedly increased from $15.2 \%$ in 1991 (WHO) to $56.5 \%$ in 2012 (this study). Meanwhile, the proportion of households relying on solid fuels for cooking has decreased from 93.5\% in 1991 to $61.2 \%$ in 2012 in rural areas, and from $66.3 \%$ to $20.3 \%$ in urban areas. Interestingly, while coal use declined in both rural and urban areas from 1991 (43.5\% and 53.8\%, respectively) to 2012 (13.5\% and $8.3 \%$, respectively), biomass use dropped continuously from 1991 to 2006 , and then appeared to rebound. For example, nearly $50.0 \%$ of rural households relied on biomass fuel for cooking in 1991 , and this decreased to $26.1 \%$ in 2006 , but in 2012 , $47.6 \%$ of rural households identified in the present investigation used biomass for cooking. Data about HFU for cooking were obtained from different datasets, which may cause considerable bias and uncertainty in data comparison, due to the different research methods adopted. However, it is likely that the proportion of residents using biomass fuels as their main or primary fuel source may have increased under the development of new clean/renewable energy technologies $[16,17]$. Recent policy changes have encouraged the use of carbon-neutral biomass fuels as opposed to fossil-fuel alternatives. Also, over the last 5 years, coal prices have increased, driven by industrial coal demand and the short supply of coal, so biomass fuel may provide a more affordable option to users. Long-term research will be required to verify temporal variations in fuel use. Also, it is important to note that although our results indicate that the proportion of solid-fuel users decreased from 1991 to 2012, since the overall population in China increased significantly (from 1.16 billion in 1991 to 1.35 billion in 2012), the absolute number of people using solid fuels was still extremely large (Table S2). This suggests that a significant number of people are potentially exposed to harmful pollutants, and consequently at high risk for the development of disease, as inefficient burning of solid fuels often yield a large number of incomplete pollutants [18-20].

The HFU pattern typically varies dramatically among the provinces due to many factors, including fuel-energy storage and accessibility, household fuel cooking habits, and different family income levels. The provincial HFU results for cooking for urban and rural areas in each province are listed in Table 2. Shanghai, Beijing, Tianjin, and Jiangsu, which are relatively developed provinces, had a

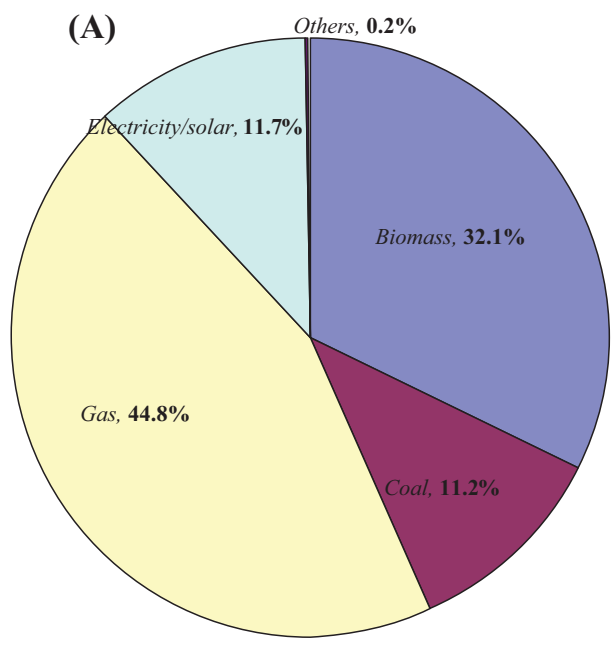

(B)

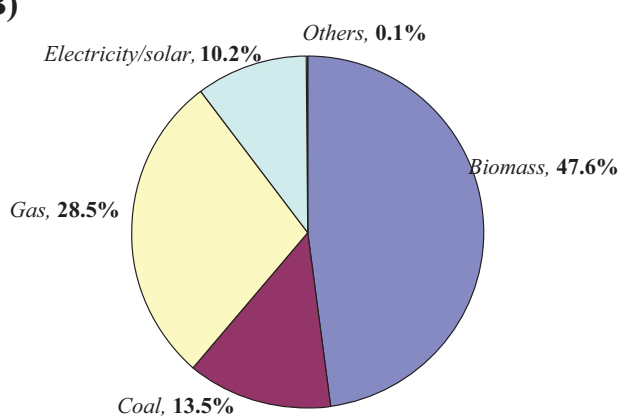

(C)

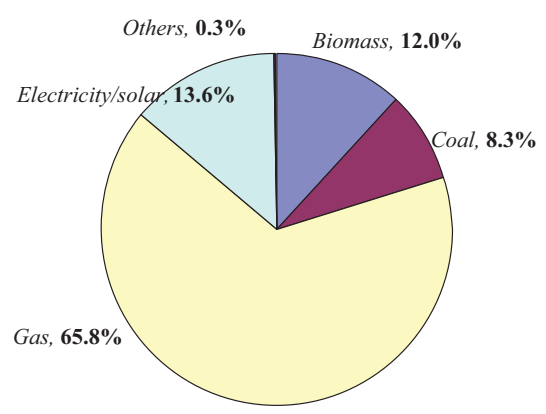

Fig. 2. HFU patterns for cooking in China over the whole country (A), in rural (B) and urban (C) areas. 

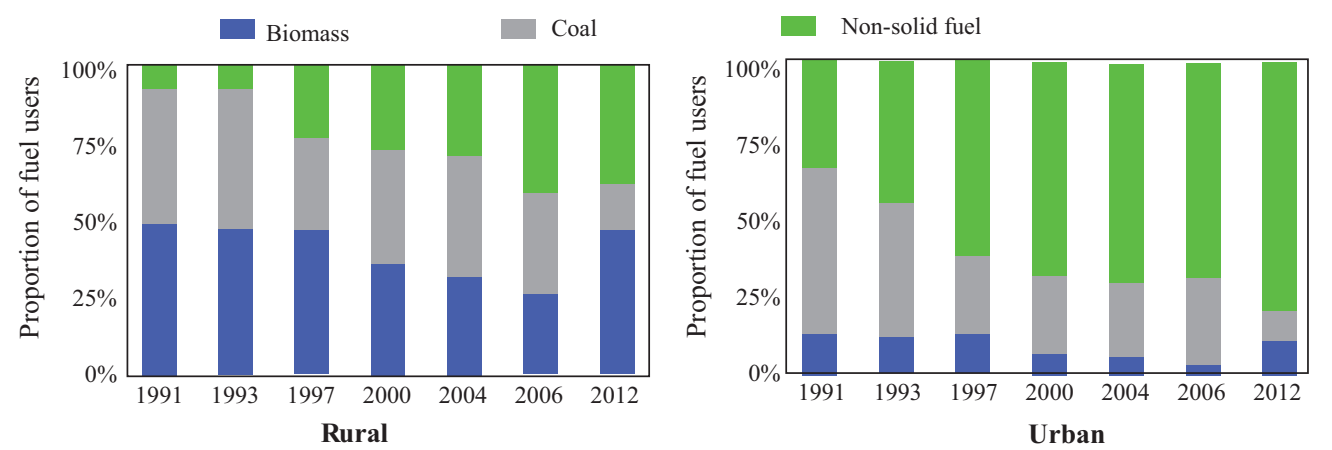

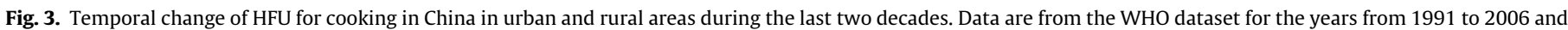
present study for 2012, as listed in Table S1 in detail.

much higher proportion of non-SFU. At least $70 \%$ of households in these four provinces used gas for cooking (93.5\%, 88.9\%, 78.3\%, and $72.6 \%$ in Shanghai, Beijing, Tianjin, and Jiangsu, respectively). Provinces located in western China, such as Gansu, Yunnan, Guizhou, and Qinghai, relied much less on gas for household cooking. In contrast to cleaner fuels, such as electricity and gas, the use of solid fuel types was highly correlated with local fuel availability. For example, Shanxi province is the largest coal storage province in China, and many inhabitants used coal for daily household cooking; coal contributed as much as $45.4 \%$ of the total HFU. In the provinces of Xizang and Xinjiang, in which there is a large nomad population, and provinces such as Jilin, Liaoning, and Heilongjiang in northeastern China that have a high abundance of forested areas, biomass comprised more than half of the total HFU for cooking.
In terms of the rural-urban difference in the provincial HFU patterns, in general, urban residents mainly used non-solid fuels for cooking, especially gas comprising up to over $50 \%$ of the total fuel used for cooking in most provinces. Less than 30\% of households in Yunnan (12.4\%), Qinghai (14.5\%), Guizhou (18.2\%) and Gansu (23.1\%) used gas for cooking. In Gansu, biomass (34.0\%) and coal (19.3\%) were commonly used for household cooking, but in Yunnan, Qinghai and Guizhou, most households (58.0\%, $79.5 \%$ and $60.1 \%$, respectively) used solar/electricity for cooking. In rural areas, use of solid or non-solid fuels varied significantly among provinces. For example, in rural Beijing, gas contributed $\sim 82.7 \%$ of the total HFU for cooking, but in rural Ningxia, more than $69.5 \%$ of households used solar/electricity for cooking. In general, the provinces located in eastern China, such as Guangdong,

Table 1

Number and regional distribution of recruited households in this study.

\begin{tabular}{|c|c|c|c|c|c|c|c|}
\hline \multirow[t]{2}{*}{ No } & \multirow[t]{2}{*}{ Province name } & \multirow[t]{2}{*}{ Number of cities/counties } & \multirow[t]{2}{*}{ Number of towns } & \multirow[t]{2}{*}{ Number of villages/suburban } & \multicolumn{3}{|c|}{ Number of households recruited } \\
\hline & & & & & Total & Rural & Urban \\
\hline 1 & Anhui & 6 & 24 & 72 & 3497 & 1603 & 1894 \\
\hline 2 & Beijing & 2 & 8 & 24 & 1114 & 274 & 840 \\
\hline 3 & Fujian & 5 & 20 & 60 & 2898 & 1403 & 1495 \\
\hline 4 & Gansu & 5 & 20 & 60 & 2869 & 2070 & 799 \\
\hline 5 & Guangdong & 6 & 24 & 72 & 3250 & 1499 & 1751 \\
\hline 6 & Guangsi & 6 & 24 & 72 & 3380 & 2036 & 1344 \\
\hline 7 & Guizhou & 5 & 20 & 60 & 2855 & 1793 & 1062 \\
\hline 8 & Hainan & 2 & 8 & 24 & 1083 & 755 & 328 \\
\hline 9 & Hebei & 8 & 32 & 96 & 4409 & 2578 & 1831 \\
\hline 10 & Henan & 8 & 32 & 96 & 4931 & 2891 & 2040 \\
\hline 11 & Heilongjiang & 7 & 28 & 84 & 4062 & 2473 & 1589 \\
\hline 12 & Hubei & 6 & 24 & 72 & 3412 & 1027 & 2385 \\
\hline 13 & Hunan & 7 & 28 & 84 & 4059 & 2525 & 1534 \\
\hline 14 & Jilin & 5 & 20 & 60 & 2738 & 1166 & 1572 \\
\hline 15 & Jiangsu & 6 & 24 & 72 & 3473 & 1160 & 2313 \\
\hline 16 & Jiangxi & 5 & 20 & 60 & 2917 & 1197 & 1720 \\
\hline 17 & Liaoning & 6 & 24 & 72 & 3379 & 2184 & 1195 \\
\hline 18 & Neimeng & 5 & 20 & 60 & 3048 & 1852 & 1196 \\
\hline 19 & Ningxia & 2 & 8 & 24 & 1138 & 98 & 1040 \\
\hline 20 & Qinghai & 3 & 12 & 36 & 1592 & 926 & 666 \\
\hline 21 & Shandong & 9 & 36 & 108 & 5591 & 2881 & 2710 \\
\hline 22 & Shanxi & 6 & 24 & 72 & 3441 & 2394 & 1047 \\
\hline 23 & Shaanxi & 5 & 20 & 60 & 2868 & 1537 & 1331 \\
\hline 24 & Shanghai & 2 & 8 & 24 & 1161 & & 1161 \\
\hline 25 & Sichuan & 8 & 32 & 96 & 4581 & 2641 & 1940 \\
\hline 26 & Tianjin & 2 & 8 & 24 & 1154 & 289 & 865 \\
\hline 27 & Xizang & 3 & 12 & 36 & 1529 & 1144 & 385 \\
\hline 28 & Xinjiang & 5 & 20 & 60 & 2804 & 1585 & 1219 \\
\hline 29 & Yunnan & 6 & 24 & 72 & 3491 & 2577 & 914 \\
\hline 30 & Zhejiang & 6 & 24 & 72 & 3428 & 2244 & 1184 \\
\hline \multirow[t]{2}{*}{31} & Chongqing & 2 & 8 & 24 & 969 & 493 & 476 \\
\hline & Total & 159 & 636 & 1908 & 91,121 & 49,295 & 41,826 \\
\hline
\end{tabular}


Table 2

The proportion of different HFU patterns for cooking in China (\%).

\begin{tabular}{|c|c|c|c|c|c|c|c|}
\hline & \multirow[t]{2}{*}{ Provinces } & \multicolumn{6}{|c|}{ The proportion of different HFU patterns for cooking in China (\%) } \\
\hline & & Areas & Biomass fuels (\%) & Coal (\%) & Gas (\%) & Solar/Elec (\%) & Others (\%) \\
\hline \multirow[t]{3}{*}{1} & Beijing & Urban & 0.6 & 3.1 & 91.3 & 4.7 & 0.4 \\
\hline & & Rural & 6.5 & 5.8 & 82.7 & 4.0 & 1.1 \\
\hline & & Total & 2.2 & 3.8 & 88.9 & 4.5 & 0.6 \\
\hline \multirow[t]{3}{*}{2} & Tianjin & Urban & 17.5 & 0.3 & 81.7 & 0.3 & 0.1 \\
\hline & & Rural & 27.4 & 0.0 & 72.5 & 0.1 & 0.0 \\
\hline & & Total & 21.2 & 0.2 & 78.3 & 0.2 & 0.1 \\
\hline \multirow[t]{3}{*}{3} & Hebei & Urban & 5.5 & 10.9 & 78.6 & 4.7 & 0.3 \\
\hline & & Rural & 23.1 & 30.3 & 31.2 & 15.4 & 0.0 \\
\hline & & Total & 14.8 & 21.2 & 53.5 & 10.3 & 0.2 \\
\hline \multirow[t]{3}{*}{4} & Shanxi & Urban & 0.9 & 14.3 & 55.4 & 29.0 & 0.5 \\
\hline & & Rural & 19.7 & 58.6 & 4.5 & 17.1 & 0.0 \\
\hline & & Total & 14.1 & 45.4 & 19.7 & 20.6 & 0.1 \\
\hline \multirow[t]{3}{*}{5} & Neimenggu & Urban & 9.3 & 11.5 & 64.1 & 15.1 & 0.0 \\
\hline & & Rural & 85.5 & 5.7 & 5.6 & 3.2 & 0.0 \\
\hline & & Total & 54.1 & 8.1 & 29.7 & 8.1 & 0.0 \\
\hline \multirow[t]{3}{*}{6} & Liaoning & Urban & 17.9 & 5.4 & 67.9 & 8.5 & 0.3 \\
\hline & & Rural & 75.8 & 3.1 & 13.9 & 7.2 & 0.0 \\
\hline & & Total & 60.4 & 3.7 & 28.3 & 7.5 & 0.1 \\
\hline \multirow[t]{3}{*}{7} & Jilin & Urban & 35.4 & 4.4 & 51.9 & 8.2 & 0.1 \\
\hline & & Rural & 82.4 & 0.3 & 15.5 & 1.7 & 0.0 \\
\hline & & Total & 59.5 & 2.3 & 33.2 & 4.9 & 0.1 \\
\hline \multirow[t]{3}{*}{8} & Heilongjiang & Urban & 9.8 & 15.3 & 52.8 & 22.1 & 0.1 \\
\hline & & Rural & 76.5 & 7.3 & 5.9 & 10.3 & 0.0 \\
\hline & & Total & 51.4 & 10.3 & 23.5 & 14.8 & 0.0 \\
\hline \multirow[t]{3}{*}{9} & Shanghai & Urban & 0.3 & 3.2 & 93.5 & 1.6 & 1.4 \\
\hline & & Rural & 1 & 1 & 1 & 1 & 1 \\
\hline & & Total & 0.3 & 3.2 & 93.5 & 1.6 & 1.4 \\
\hline \multirow[t]{3}{*}{10} & Jiangsu & Urban & 9.0 & 2.0 & 80.6 & 8.3 & 0.2 \\
\hline & & Rural & 35.7 & 0.7 & 55.7 & 7.9 & 0.0 \\
\hline & & Total & 17.6 & 1.6 & 72.6 & 8.1 & 0.2 \\
\hline \multirow[t]{3}{*}{11} & Zhejiang & Urban & 10.8 & 2.1 & 86.4 & 0.6 & 0.1 \\
\hline & & Rural & 37.8 & 1.8 & 56.2 & 4.1 & 0.1 \\
\hline & & Total & 29.0 & 1.9 & 66.0 & 3.0 & 0.1 \\
\hline \multirow[t]{3}{*}{12} & Anhui & Urban & 20.6 & 2.3 & 72.8 & 4.1 & 0.1 \\
\hline & & Rural & 50.6 & 7.1 & 38.4 & 3.8 & 0.0 \\
\hline & & Total & 39.2 & 5.3 & 51.5 & 3.9 & 0.0 \\
\hline \multirow[t]{3}{*}{13} & Fujian & Urban & 8.8 & 0.6 & 73.1 & 17.0 & 0.6 \\
\hline & & Rural & 28.5 & 1.6 & 50.5 & 19.3 & 0.1 \\
\hline & & Total & 18.7 & 1.1 & 61.7 & 18.2 & 0.3 \\
\hline \multirow[t]{3}{*}{14} & Jiangxi & Urban & 12.0 & 11.5 & 60.0 & 16.3 & 0.1 \\
\hline & & Rural & 46.7 & 22.0 & 16.7 & 14.4 & 0.1 \\
\hline & & Total & 28.7 & 16.6 & 39.2 & 15.4 & 0.1 \\
\hline \multirow[t]{3}{*}{15} & Shandong & Urban & 9.9 & 3.9 & 82.2 & 3.8 & 0.3 \\
\hline & & Rural & 40.0 & 4.1 & 46.7 & 8.6 & 0.6 \\
\hline & & Total & 24.0 & 4.0 & 65.5 & 6.1 & 0.4 \\
\hline \multirow[t]{3}{*}{16} & Henan & Urban & 10.4 & 28.4 & 49.7 & 11.3 & 0.2 \\
\hline & & Rural & 41.4 & 23.3 & 27.2 & 8.2 & 0.0 \\
\hline & & Total & 32.6 & 24.7 & 33.6 & 9.1 & 0.0 \\
\hline
\end{tabular}




\begin{tabular}{|c|c|c|c|c|c|c|c|}
\hline 17 & Hubei & $\begin{array}{l}\text { Urban } \\
\text { Rural } \\
\text { Total }\end{array}$ & $\begin{array}{l}15.2 \\
39.6 \\
24.0\end{array}$ & $\begin{array}{r}9.1 \\
12.6 \\
10.4\end{array}$ & $\begin{array}{l}71.6 \\
47.2 \\
62.8\end{array}$ & $\begin{array}{l}2.8 \\
0.6 \\
2.0\end{array}$ & $\begin{array}{l}1.2 \\
0.0 \\
0.8\end{array}$ \\
\hline 18 & Hunan & $\begin{array}{l}\text { Urban } \\
\text { Rural } \\
\text { Total }\end{array}$ & $\begin{array}{r}0.8 \\
41.8 \\
30.2\end{array}$ & $\begin{array}{l}28.5 \\
26.1 \\
26.8\end{array}$ & $\begin{array}{l}67.3 \\
27.9 \\
39.0\end{array}$ & $\begin{array}{l}3.1 \\
4.1 \\
3.8\end{array}$ & $\begin{array}{l}0.4 \\
0.1 \\
0.1\end{array}$ \\
\hline 19 & Guangdong & $\begin{array}{l}\text { Urban } \\
\text { Rural } \\
\text { Total }\end{array}$ & $\begin{array}{r}8.8 \\
28.1 \\
18.1\end{array}$ & $\begin{array}{r}5.2 \\
11.4 \\
8.2\end{array}$ & $\begin{array}{l}68.8 \\
54.5 \\
62.0\end{array}$ & $\begin{array}{r}17.1 \\
6.0 \\
11.8\end{array}$ & $\begin{array}{l}0.0 \\
0.1 \\
0.0\end{array}$ \\
\hline 20 & Guangxi & $\begin{array}{l}\text { Urban } \\
\text { Rural } \\
\text { Total }\end{array}$ & $\begin{array}{l}23.4 \\
55.6 \\
46.5\end{array}$ & $\begin{array}{l}2.7 \\
2.8 \\
2.7\end{array}$ & $\begin{array}{l}65.7 \\
35.0 \\
43.7\end{array}$ & $\begin{array}{l}7.8 \\
6.6 \\
6.9\end{array}$ & $\begin{array}{l}0.4 \\
0.0 \\
0.1\end{array}$ \\
\hline 21 & Hainan & $\begin{array}{l}\text { Urban } \\
\text { Rural } \\
\text { Total }\end{array}$ & $\begin{array}{l}22.2 \\
47.9 \\
40.4\end{array}$ & $\begin{array}{l}1.7 \\
4.5 \\
3.7\end{array}$ & $\begin{array}{l}71.0 \\
43.9 \\
51.7\end{array}$ & $\begin{array}{l}5.1 \\
3.2 \\
3.8\end{array}$ & $\begin{array}{l}0.0 \\
0.6 \\
0.4\end{array}$ \\
\hline 22 & Chongqing & $\begin{array}{l}\text { Urban } \\
\text { Rural } \\
\text { Total }\end{array}$ & $\begin{array}{l}11.8 \\
66.6 \\
38.9\end{array}$ & $\begin{array}{l}2.3 \\
4.7 \\
3.5\end{array}$ & $\begin{array}{l}68.4 \\
12.8 \\
40.9\end{array}$ & $\begin{array}{l}17.1 \\
16.0 \\
16.5\end{array}$ & $\begin{array}{l}0.4 \\
0.0 \\
0.2\end{array}$ \\
\hline 23 & Sichuan & $\begin{array}{l}\text { Urban } \\
\text { Rural } \\
\text { Total }\end{array}$ & $\begin{array}{l}17.0 \\
47.9 \\
36.6\end{array}$ & $\begin{array}{l}11.1 \\
10.3 \\
10.6\end{array}$ & $\begin{array}{l}46.7 \\
20.9 \\
30.3\end{array}$ & $\begin{array}{l}25.0 \\
20.9 \\
22.4\end{array}$ & $\begin{array}{l}0.2 \\
0.0 \\
0.1\end{array}$ \\
\hline 24 & Guizhou & $\begin{array}{l}\text { Urban } \\
\text { Rural } \\
\text { Total }\end{array}$ & $\begin{array}{r}2.4 \\
23.0 \\
12.9\end{array}$ & $\begin{array}{l}18.2 \\
43.5 \\
31.0\end{array}$ & $\begin{array}{r}18.2 \\
2.6 \\
10.3\end{array}$ & $\begin{array}{l}60.1 \\
30.3 \\
45.0\end{array}$ & $\begin{array}{l}1.0 \\
0.6 \\
0.8\end{array}$ \\
\hline 25 & Yunnan & $\begin{array}{l}\text { Urban } \\
\text { Rural } \\
\text { Total }\end{array}$ & $\begin{array}{l}24.9 \\
55.7 \\
46.6\end{array}$ & $\begin{array}{l}4.7 \\
6.6 \\
6.1\end{array}$ & $\begin{array}{r}12.4 \\
5.6 \\
7.6\end{array}$ & $\begin{array}{l}58.0 \\
31.8 \\
39.5\end{array}$ & $\begin{array}{l}0.0 \\
0.2 \\
0.2\end{array}$ \\
\hline 26 & Xizang & $\begin{array}{l}\text { Urban } \\
\text { Rural } \\
\text { Total }\end{array}$ & $\begin{array}{r}4.1 \\
88.3 \\
69.5\end{array}$ & $\begin{array}{l}1.8 \\
0.6 \\
0.9\end{array}$ & $\begin{array}{l}93.7 \\
11.1 \\
29.5\end{array}$ & $\begin{array}{l}0.2 \\
0.0 \\
0.0\end{array}$ & $\begin{array}{l}0.2 \\
0.0 \\
0.0\end{array}$ \\
\hline 27 & Shaanxi & $\begin{array}{l}\text { Urban } \\
\text { Rural } \\
\text { Total }\end{array}$ & $\begin{array}{l}16.0 \\
70.5 \\
46.0\end{array}$ & $\begin{array}{r}12.1 \\
8.7 \\
10.2\end{array}$ & $\begin{array}{l}50.1 \\
11.1 \\
28.7\end{array}$ & $\begin{array}{r}21.5 \\
9.4 \\
14.9\end{array}$ & $\begin{array}{l}0.3 \\
0.2 \\
0.2\end{array}$ \\
\hline 28 & Gansu & $\begin{array}{l}\text { Urban } \\
\text { Rural } \\
\text { Total }\end{array}$ & $\begin{array}{l}34.0 \\
68.0 \\
59.5\end{array}$ & $\begin{array}{l}19.3 \\
18.8 \\
19.0\end{array}$ & $\begin{array}{r}23.1 \\
9.4 \\
12.8\end{array}$ & $\begin{array}{r}23.6 \\
3.7 \\
8.7\end{array}$ & $\begin{array}{l}0.1 \\
0.1 \\
0.1\end{array}$ \\
\hline 29 & Qinghai & $\begin{array}{l}\text { Urban } \\
\text { Rural } \\
\text { Total }\end{array}$ & $\begin{array}{r}0.1 \\
33.5 \\
10.3\end{array}$ & $\begin{array}{r}5.9 \\
52.9 \\
20.2\end{array}$ & $\begin{array}{r}14.5 \\
1.3 \\
10.5\end{array}$ & $\begin{array}{l}79.5 \\
12.3 \\
59.0\end{array}$ & $\begin{array}{l}0.1 \\
0.0 \\
0.1\end{array}$ \\
\hline 30 & Ningxia & $\begin{array}{l}\text { Urban } \\
\text { Rural } \\
\text { Total }\end{array}$ & $\begin{array}{l}1.8 \\
0.7 \\
1.7\end{array}$ & $\begin{array}{l}3.6 \\
1.8 \\
3.4\end{array}$ & $\begin{array}{l}65.1 \\
28.1 \\
61.5\end{array}$ & $\begin{array}{l}29.0 \\
69.5 \\
33.0\end{array}$ & $\begin{array}{l}0.5 \\
0.0 \\
0.5\end{array}$ \\
\hline 31 & Xinjiang & $\begin{array}{l}\text { Urban } \\
\text { Rural } \\
\text { Total }\end{array}$ & $\begin{array}{l}33.7 \\
88.0 \\
69.7\end{array}$ & $\begin{array}{l}15.8 \\
10.9 \\
12.5\end{array}$ & $\begin{array}{r}50.0 \\
1.1 \\
17.6\end{array}$ & $\begin{array}{l}0.5 \\
0.1 \\
0.2\end{array}$ & $\begin{array}{l}0.0 \\
0.0 \\
0.0\end{array}$ \\
\hline
\end{tabular}


Fujian, Zhejiang, Jiangsu, Shandong, and Tianjin, used non-solid fuel as the major fuel source, contributing to $55.3-72.5 \%$ of the total. In other provinces, rural residents mainly used solid fuels for cooking. Such differences are highly related to fuel abundance and residents' cooking habits.

\subsection{HFU for heating in China and spatial variation}

To our knowledge, no data have been published HFU for heating in China. The present survey provides the first estimates (Fig. 4). Approximately $34.1 \%$ of households in China had no means of household heating. Nationwide, $\sim 10.3 \%$ of households used a central heating system, and $8.9 \%$ of households used individual heating, in which natural or liquid petroleum gas was burned to heat water. The proportions of households using coal, electricity and biomass for heating were $16.7 \%, 15.6 \%$, and $12.8 \%$, respectively.

Different patterns of HFU for heating could be found between the rural and urban households. In rural areas, most households lacked central heating, so residents largely burned traditional solid fuels (21.5\% used coal and $19.0 \%$ used biomass) for heating. In urban areas, approximately $22.0 \%$ of households had central heating. Most urban residents used electricity/solar power (23.6\%), followed by coal (10.5\%) for the household heating. Little information is available regarding historical patterns of HFU for heating in China, so this paper does not discuss temporal changes in the HFU for heating.

Provincial HFU results for heating are also available in our present investigation and listed in Table 3. Winter heating is known to be very common in northern China, while many households (33.898.3\%) in southern China were not heated during the cold season. More than $30 \%$ of households in only a few provinces had central heating, such as Ningxia (59.5\%), Qinghai (44.8\%), Shandong (33.2\%), Heilongjiang (32.9\%), Beijing (35.1\%), and Hebei (30.9\%). In most areas of China, households used electricity, gas, or traditional solid fuels for heating. In relatively developed provinces in east or southeast China, and the North China Plain, more households relied on non-solid fuels. In western provinces, residents mainly used solid fuels for household heating.

When examining urban-rural differences, our results showed that a higher proportion of urban households relied on a central heating system. In provinces near the mid to lower reaches of the Yangtze River, such as Hunan, Hubei, Anhui, Jiangxi, Jiangsu, and Shanghai, many residents (approximately $85.1 \%, 39.4 \%$, $34.4 \%, 53.5 \%, 46.7 \%$, and $64.2 \%$, respectively) used electricity for household heating. Solid fuels were the main heat source in only a few provinces: Gansu ( $74.0 \%$ coal), Guizhou (54.2\% coal and $5.4 \%$ biomass), Jilin (37.1\% biomass and $10.5 \%$ coal), Shanxi (27.7\% coal and $0.8 \%$ biomass), and Shaanxi (25.3\% coal and $22.6 \%$ biomass). In rural areas, central heating was very rare; less than $10 \%$ of rural households relied on central heat in all provinces. In Tianjin, Heilongjiang, Beijing, and Liaoning provinces, 87.9\%, $74.4 \%, 66.8 \%$, and $60.6 \%$, respectively, used individual heating. In other provinces, such as Xizang, Qinghai and Ningxia, solid fuels were generally used, with more than $95 \%$ of rural households relying on biomass and coal for heating.

\subsection{Factors affecting HFU patterns}

As discussed above, patterns in HFU for cooking and heating varied dramatically among different provinces and between rural and urban households. Changes in HFU are likely associated with economic level, the availability of solid fuels, and the availability of alternative, cleaner fuels [4,21]. Fig. 5 illustrates changes in the percentage of households using gas or coal for cooking in urban China over the last two decades, as a function of income per capita. During the last two decades, the number of gas users increased along with this increasing incoming per capita, while solid fuel (biomass, coal) users decreased. A statistically significant $(p<0.05)$ relationship between HFU and income per capita was identified, and this parameter alone could explain over $80 \%$ of the variations in the HFU for cooking.
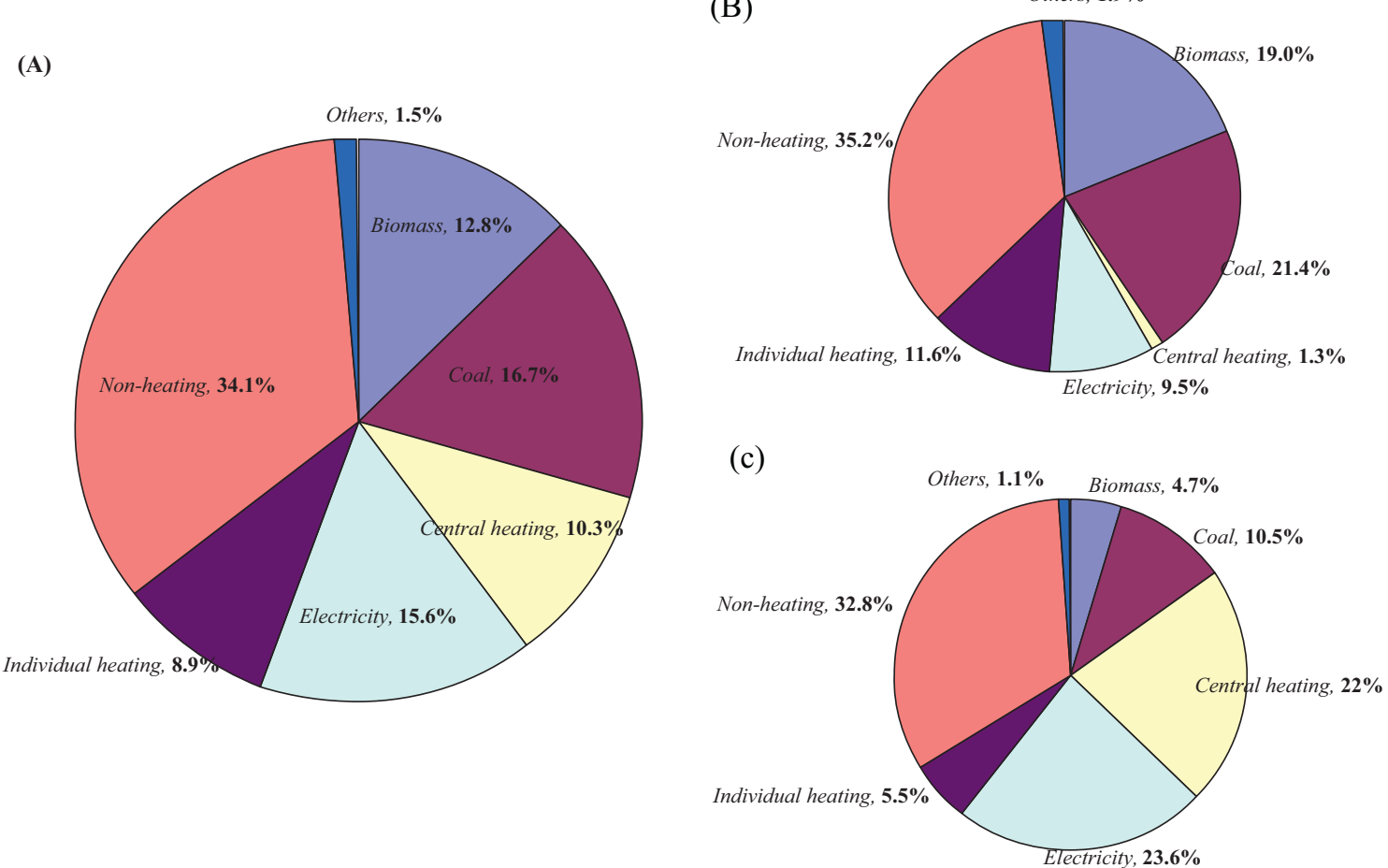

Fig. 4. HFU patterns for heating in China over the whole country (A), in rural (B) and urban (C) areas. 
Table 3

The proportion of different HFU patterns for heating in China (\%).

\begin{tabular}{|c|c|c|c|c|c|c|c|c|c|c|}
\hline & \multirow[t]{2}{*}{ Provinces } & \multirow[t]{2}{*}{ Areas } & \multicolumn{7}{|c|}{ The proportion of different HFU patterns for heating in China (\%) } & \multirow{2}{*}{$\begin{array}{l}\text { Heating duratiol } \\
\text { (Days/year) }^{a}\end{array}$} \\
\hline & & & Central heating (\%) & Individual heating (\%) & Coal $(\%)$ & Biomass (\%) & Electricity (\%) & Non-heating (\%) & Others $(\%)$ & \\
\hline 1 & Beijing & $\begin{array}{l}\text { Urban } \\
\text { Rural } \\
\text { Total }\end{array}$ & $\begin{array}{r}48.5 \\
0.6 \\
35.1\end{array}$ & $\begin{array}{l}20.2 \\
66.8 \\
33.2\end{array}$ & $\begin{array}{l}13.6 \\
19.4 \\
15.2\end{array}$ & $\begin{array}{l}0.6 \\
2.1 \\
1.0\end{array}$ & $\begin{array}{r}16.0 \\
9.3 \\
14.1\end{array}$ & $\begin{array}{l}1.0 \\
1.0 \\
1.0\end{array}$ & $\begin{array}{l}0.1 \\
0.8 \\
0.3\end{array}$ & $148 \pm 24$ \\
\hline 2 & Tianjin & $\begin{array}{l}\text { Urban } \\
\text { Rural } \\
\text { Total }\end{array}$ & $\begin{array}{r}46.0 \\
0.5 \\
28.8\end{array}$ & $\begin{array}{l}36.1 \\
87.9 \\
55.6\end{array}$ & $\begin{array}{l}8.2 \\
9.7 \\
8.7\end{array}$ & $\begin{array}{l}7.1 \\
0.0 \\
4.4\end{array}$ & $\begin{array}{l}1.5 \\
0.5 \\
1.1\end{array}$ & $\begin{array}{l}1.1 \\
1.4 \\
1.3\end{array}$ & $\begin{array}{l}0.0 \\
0.0 \\
0.0\end{array}$ & $82 \pm 35$ \\
\hline 3 & Hebei & $\begin{array}{l}\text { Urban } \\
\text { Rural } \\
\text { Total }\end{array}$ & $\begin{array}{r}64.1 \\
1.5 \\
30.9\end{array}$ & $\begin{array}{l}12.2 \\
30.0 \\
21.6\end{array}$ & $\begin{array}{l}21.3 \\
58.2 \\
40.9\end{array}$ & $\begin{array}{l}1.5 \\
8.4 \\
5.2\end{array}$ & $\begin{array}{l}0.8 \\
1.3 \\
1.0\end{array}$ & $\begin{array}{l}0.2 \\
0.5 \\
0.4\end{array}$ & $\begin{array}{l}0.0 \\
0.0 \\
0.0\end{array}$ & $108 \pm 72$ \\
\hline 4 & Shanxi & $\begin{array}{l}\text { Urban } \\
\text { Rural } \\
\text { Total }\end{array}$ & $\begin{array}{r}59.2 \\
1.5 \\
18.7\end{array}$ & $\begin{array}{r}11.5 \\
9.4 \\
10.0\end{array}$ & $\begin{array}{l}27.7 \\
81.2 \\
65.2\end{array}$ & $\begin{array}{l}0.8 \\
6.9 \\
5.1\end{array}$ & $\begin{array}{l}0.8 \\
0.7 \\
0.8\end{array}$ & $\begin{array}{l}0.2 \\
0.3 \\
0.2\end{array}$ & $\begin{array}{l}0.0 \\
0.0 \\
0.0\end{array}$ & $67 \pm 39$ \\
\hline 5 & Neimenggu & $\begin{array}{l}\text { Urban } \\
\text { Rural } \\
\text { Total }\end{array}$ & $\begin{array}{r}65.1 \\
2.0 \\
28.0\end{array}$ & $\begin{array}{l}20.8 \\
36.8 \\
30.2\end{array}$ & $\begin{array}{l}13.4 \\
26.2 \\
20.9\end{array}$ & $\begin{array}{r}0.6 \\
35.0 \\
20.8\end{array}$ & $\begin{array}{l}0.0 \\
0.0 \\
0.0\end{array}$ & $\begin{array}{l}0.1 \\
0.0 \\
0.0\end{array}$ & $\begin{array}{l}0.0 \\
0.0 \\
0.0\end{array}$ & $103 \pm 51$ \\
\hline 6 & Liaoning & $\begin{array}{l}\text { Urban } \\
\text { Rural } \\
\text { Total }\end{array}$ & $\begin{array}{r}59.8 \\
2.0 \\
17.4\end{array}$ & $\begin{array}{l}23.6 \\
60.6 \\
50.7\end{array}$ & $\begin{array}{l}5.1 \\
8.9 \\
7.9\end{array}$ & $\begin{array}{l}10.7 \\
22.5 \\
19.4\end{array}$ & $\begin{array}{l}0.1 \\
0.1 \\
0.1\end{array}$ & $\begin{array}{l}0.7 \\
3.2 \\
2.5\end{array}$ & $\begin{array}{l}0.1 \\
2.7 \\
2.0\end{array}$ & $190 \pm 31$ \\
\hline 7 & Jilin & $\begin{array}{l}\text { Urban } \\
\text { Rural } \\
\text { Total }\end{array}$ & $\begin{array}{r}49.2 \\
7.7 \\
27.9\end{array}$ & $\begin{array}{r}3.1 \\
11.4 \\
7.4\end{array}$ & $\begin{array}{r}10.5 \\
9.1 \\
9.8\end{array}$ & $\begin{array}{l}37.1 \\
71.7 \\
54.9\end{array}$ & $\begin{array}{l}0.0 \\
0.0 \\
0.0\end{array}$ & $\begin{array}{l}0.0 \\
0.1 \\
0.0\end{array}$ & $\begin{array}{l}0.0 \\
0.0 \\
0.0\end{array}$ & $74 \pm 28$ \\
\hline 8 & Heilongjiang & $\begin{array}{l}\text { Urban } \\
\text { Rural } \\
\text { Total }\end{array}$ & $\begin{array}{r}75.9 \\
6.8 \\
32.9\end{array}$ & $\begin{array}{l}17.5 \\
74.4 \\
53.0\end{array}$ & $\begin{array}{l}3.3 \\
5.7 \\
4.8\end{array}$ & $\begin{array}{r}3.2 \\
12.9 \\
9.3\end{array}$ & $\begin{array}{l}0.1 \\
0.0 \\
0.0\end{array}$ & $\begin{array}{l}0.0 \\
0.0 \\
0.0\end{array}$ & $\begin{array}{l}0.0 \\
0.0 \\
0.0\end{array}$ & $143 \pm 45$ \\
\hline 9 & Shanghai & $\begin{array}{l}\text { Urban } \\
\text { Rural } \\
\text { Total }\end{array}$ & $\backslash_{0.0}^{0.0}$ & $\backslash_{1.2}^{1.2}$ & $\backslash^{0.0}$ & $\backslash_{0.0}^{0.0}$ & $\begin{array}{l}64.2 \\
\backslash \\
64.2\end{array}$ & $\begin{array}{l}33.8 \\
\backslash \\
33.8\end{array}$ & $\backslash^{0.8}$ & $162 \pm 22$ \\
\hline 10 & Jiangsu & $\begin{array}{l}\text { Urban } \\
\text { Rural } \\
\text { Total }\end{array}$ & $\begin{array}{l}0.9 \\
0.0 \\
0.6\end{array}$ & $\begin{array}{l}0.5 \\
0.0 \\
0.3\end{array}$ & $\begin{array}{l}2.4 \\
0.1 \\
1.6\end{array}$ & $\begin{array}{l}0.1 \\
0.2 \\
0.1\end{array}$ & $\begin{array}{l}46.7 \\
34.3 \\
42.7\end{array}$ & $\begin{array}{l}48.9 \\
65.0 \\
54.1\end{array}$ & $\begin{array}{l}0.7 \\
0.4 \\
0.6\end{array}$ & $163 \pm 32$ \\
\hline 11 & Zhejiang & $\begin{array}{l}\text { Urban } \\
\text { Rural } \\
\text { Total }\end{array}$ & $\begin{array}{l}0.3 \\
0.0 \\
0.1\end{array}$ & $\begin{array}{l}0.0 \\
0.7 \\
0.5\end{array}$ & $\begin{array}{l}0.3 \\
0.9 \\
0.7\end{array}$ & $\begin{array}{l}0.9 \\
3.4 \\
2.6\end{array}$ & $\begin{array}{l}49.0 \\
18.3 \\
28.2\end{array}$ & $\begin{array}{l}45.8 \\
65.4 \\
59.1\end{array}$ & $\begin{array}{r}3.7 \\
11.2 \\
8.8\end{array}$ & $148 \pm 24$ \\
\hline 12 & Anhui & $\begin{array}{l}\text { Urban } \\
\text { Rural } \\
\text { Total }\end{array}$ & $\begin{array}{l}0.3 \\
0.3 \\
0.3\end{array}$ & $\begin{array}{l}0.8 \\
1.1 \\
1.0\end{array}$ & $\begin{array}{l}0.6 \\
2.6 \\
1.8\end{array}$ & $\begin{array}{l}7.6 \\
2.4 \\
4.4\end{array}$ & $\begin{array}{l}34.4 \\
15.1 \\
22.4\end{array}$ & $\begin{array}{l}55.8 \\
78.4 \\
69.8\end{array}$ & $\begin{array}{l}0.5 \\
0.1 \\
0.3\end{array}$ & $163 \pm 32$ \\
\hline 13 & Fujian & $\begin{array}{l}\text { Urban } \\
\text { Rural } \\
\text { Total }\end{array}$ & $\begin{array}{l}0.0 \\
0.0 \\
0.0\end{array}$ & $\begin{array}{l}0.1 \\
0.5 \\
0.3\end{array}$ & $\begin{array}{l}0.0 \\
0.1 \\
0.0\end{array}$ & $\begin{array}{l}0.2 \\
0.3 \\
0.2\end{array}$ & $\begin{array}{l}4.0 \\
4.6 \\
4.3\end{array}$ & $\begin{array}{l}95.5 \\
94.6 \\
95.1\end{array}$ & $\begin{array}{l}0.2 \\
0.0 \\
0.1\end{array}$ & $190 \pm 31$ \\
\hline 14 & Jiangxi & $\begin{array}{l}\text { Urban } \\
\text { Rural } \\
\text { Total }\end{array}$ & $\begin{array}{l}0.0 \\
0.1 \\
0.0\end{array}$ & $\begin{array}{l}0.5 \\
1.1 \\
0.8\end{array}$ & $\begin{array}{r}6.1 \\
21.1 \\
13.3\end{array}$ & $\begin{array}{r}4.5 \\
20.3 \\
12.1\end{array}$ & $\begin{array}{l}53.5 \\
28.2 \\
41.3\end{array}$ & $\begin{array}{l}23.1 \\
12.5 \\
18.0\end{array}$ & $\begin{array}{l}12.2 \\
16.8 \\
14.4\end{array}$ & $148 \pm 24$ \\
\hline 15 & Shandong & $\begin{array}{l}\text { Urban } \\
\text { Rural } \\
\text { Total }\end{array}$ & $\begin{array}{r}58.1 \\
5.1 \\
33.2\end{array}$ & $\begin{array}{r}7.1 \\
13.4 \\
10.1\end{array}$ & $\begin{array}{l}21.5 \\
63.3 \\
41.1\end{array}$ & $\begin{array}{l}2.0 \\
4.6 \\
3.2\end{array}$ & $\begin{array}{l}4.6 \\
2.2 \\
3.5\end{array}$ & $\begin{array}{r}6.6 \\
11.3 \\
8.8\end{array}$ & $\begin{array}{l}0.0 \\
0.1 \\
0.1\end{array}$ & $45 \pm 33$ \\
\hline
\end{tabular}




\begin{tabular}{|c|c|c|c|c|c|c|c|c|c|c|}
\hline & \multirow[t]{2}{*}{ Provinces } & \multirow[t]{2}{*}{ Areas } & \multicolumn{7}{|c|}{ The proportion of different HFU patterns for heating in China (\%) } & \multirow{2}{*}{$\begin{array}{l}\text { Heating duration } \\
\left(^{(D a y s / y e a r)^{a}}\right.\end{array}$} \\
\hline & & & Central heating (\%) & Individual heating (\%) & Coal (\%) & Biomass (\%) & Electricity (\%) & Non-heating (\%) & Others (\%) & \\
\hline \multirow[t]{3}{*}{16} & Henan & Urban & 12.9 & 2.3 & 23.6 & 2.5 & 25.5 & 33.2 & 0.1 & \multirow[t]{3}{*}{$162 \pm 22$} \\
\hline & & Rural & 0.7 & 1.7 & 28.8 & 5.7 & 10.3 & 52.8 & 0.0 & \\
\hline & & Total & 4.2 & 1.8 & 27.3 & 4.8 & 14.6 & 47.2 & 0.0 & \\
\hline \multirow[t]{3}{*}{17} & Hubei & Urban & 0.3 & 0.5 & 0.7 & 2.5 & 39.4 & 56.0 & 0.5 & \multirow[t]{3}{*}{$82 \pm 35$} \\
\hline & & Rural & 0.0 & 1.4 & 1.2 & 23.3 & 10.6 & 63.3 & 0.2 & \\
\hline & & Total & 0.2 & 0.9 & 0.9 & 10.1 & 29.0 & 58.6 & 0.4 & \\
\hline \multirow[t]{3}{*}{18} & Hunan & Urban & 0.4 & 0.4 & 5.1 & 6.2 & 85.1 & 2.5 & 0.2 & \multirow[t]{3}{*}{$50 \pm 13$} \\
\hline & & Rural & 0.1 & 0.1 & 6.6 & 52.0 & 33.0 & 2.1 & 6.1 & \\
\hline & & Total & 0.2 & 0.2 & 6.2 & 39.1 & 47.7 & 2.2 & 4.4 & \\
\hline \multirow[t]{3}{*}{19} & Guangdong & Urban & 0.0 & 0.2 & 0.0 & 2.0 & 9.8 & 86.6 & 1.4 & \multirow[t]{3}{*}{$135 \pm 22$} \\
\hline & & Rural & 0.1 & 0.0 & 0.2 & 6.6 & 7.6 & 85.4 & 0.1 & \\
\hline & & Total & 0.0 & 0.1 & 0.1 & 4.2 & 8.8 & 86.0 & 0.8 & \\
\hline \multirow[t]{3}{*}{20} & Guangxi & Urban & 0.2 & 0.5 & 2.9 & 8.9 & 25.5 & 61.3 & 0.7 & \multirow[t]{3}{*}{$107 \pm 40$} \\
\hline & & Rural & 0.1 & 1.6 & 2.1 & 42.0 & 6.1 & 46.8 & 1.3 & \\
\hline & & Total & 0.1 & 1.3 & 2.3 & 32.9 & 11.4 & 50.8 & 1.1 & \\
\hline \multirow[t]{3}{*}{21} & Hainan & Urban & 0.0 & 0.0 & 0.0 & 0.2 & 0.9 & 98.7 & 0.3 & \multirow[t]{3}{*}{$67 \pm 39$} \\
\hline & & Rural & 0.0 & 0.1 & 0.0 & 0.6 & 1.0 & 98.2 & 0.2 & \\
\hline & & Total & 0.0 & 0.1 & 0.0 & 0.4 & 1.0 & 98.3 & 0.2 & \\
\hline \multirow[t]{3}{*}{22} & Chongqing & Urban & 0.0 & 0.1 & 0.5 & 6.1 & 33.5 & 59.2 & 0.6 & \multirow[t]{3}{*}{$190 \pm 31$} \\
\hline & & Rural & 0.0 & 0.2 & 0.2 & 49.0 & 5.2 & 45.6 & 0.0 & \\
\hline & & Total & 0.0 & 0.2 & 0.3 & 27.3 & 19.5 & 52.5 & 0.3 & \\
\hline \multirow[t]{3}{*}{23} & Sichuan & Urban & 0.2 & 0.2 & 3.3 & 4.2 & 38.5 & 50.3 & 3.3 & $143 \pm 45$ \\
\hline & & Rural & 1.1 & 0.8 & 4.5 & 19.8 & 10.4 & 62.5 & 0.9 & \\
\hline & & Total & 0.8 & 0.6 & 4.1 & 14.1 & 20.6 & 58.1 & 1.8 & \\
\hline 24 & Guizhou & Urban & 0.0 & 0.4 & 54.2 & 5.4 & 39.3 & 0.4 & 0.4 & $45 \pm 33$ \\
\hline & & Rural & 0.0 & 4.1 & 55.9 & 28.8 & 9.0 & 0.3 & 1.9 & \\
\hline & & Total & 0.0 & 2.2 & 55.0 & 17.2 & 24.0 & 0.4 & 1.2 & \\
\hline 25 & Yunnan & Urban & 0.2 & 3.1 & 2.0 & 19.6 & 23.2 & 46.2 & 5.7 & $163 \pm 32$ \\
\hline & & Rural & 0.0 & 2.4 & 2.4 & 30.7 & 12.3 & 47.1 & 5.1 & \\
\hline & & Total & 0.1 & 2.6 & 2.3 & 27.4 & 15.5 & 46.8 & 5.3 & \\
\hline 26 & Xizang & Urban & 0.0 & 0.2 & 4.0 & 29.9 & 32.8 & 32.5 & 0.5 & $50 \pm 13$ \\
\hline & & Rural & 0.0 & 0.0 & 0.7 & 96.8 & 0.3 & 0.9 & 1.4 & \\
\hline & & Total & 0.0 & 0.0 & 1.4 & 81.8 & 7.6 & 8.0 & 1.2 & \\
\hline 27 & Shaanxi & Urban & 28.5 & 10.6 & 25.3 & 22.6 & 12.1 & 0.9 & 0.1 & $108 \pm 72$ \\
\hline & & Rural & 0.6 & 2.1 & 56.2 & 33.9 & 5.1 & 1.2 & 0.8 & \\
\hline & & Total & 13.2 & 5.9 & 42.3 & 28.8 & 8.3 & 1.1 & 0.5 & \\
\hline 28 & Gansu & Urban & 22.4 & 2.6 & 74.0 & 0.3 & 0.1 & 0.7 & 0.0 & $103 \pm 51$ \\
\hline & & Rural & 5.3 & 1.1 & 90.6 & 1.3 & 0.0 & 1.6 & 0.0 & \\
\hline & & Total & 9.6 & 1.5 & 86.5 & 1.1 & 0.0 & 1.4 & 0.0 & \\
\hline 29 & Qinghai & Urban & 64.3 & 23.8 & 10.0 & 0.1 & 1.4 & 0.2 & 0.2 & $107 \pm 40$ \\
\hline & & Rural & 0.9 & 2.5 & 95.0 & 0.9 & 0.0 & 0.0 & 0.7 & \\
\hline & & Total & 44.8 & 17.2 & 36.1 & 0.4 & 1.0 & 0.1 & 0.4 & \\
\hline 30 & Ningxia & & & 6.0 & 27.9 & 0.0 & 0.6 & 0.0 & 0.0 & $135 \pm 22$ \\
\hline & & Rural & 4.1 & 0.0 & 95.0 & 0.0 & 0.0 & 0.0 & 0.9 & \\
\hline & & Total & 59.5 & 5.4 & 34.4 & 0.0 & 0.6 & 0.0 & 0.1 & \\
\hline 31 & Xinjiang & Urban & 47.3 & 12.5 & 28.6 & 11.6 & 0.0 & 0.0 & 0.0 & $74 \pm 28$ \\
\hline & & Rural & 0.2 & 7.0 & 54.0 & 38.8 & 0.0 & 0.0 & 0.0 & \\
\hline & & Total & 16.1 & 8.8 & 45.5 & 29.6 & 0.0 & 0.0 & 0.0 & \\
\hline
\end{tabular}




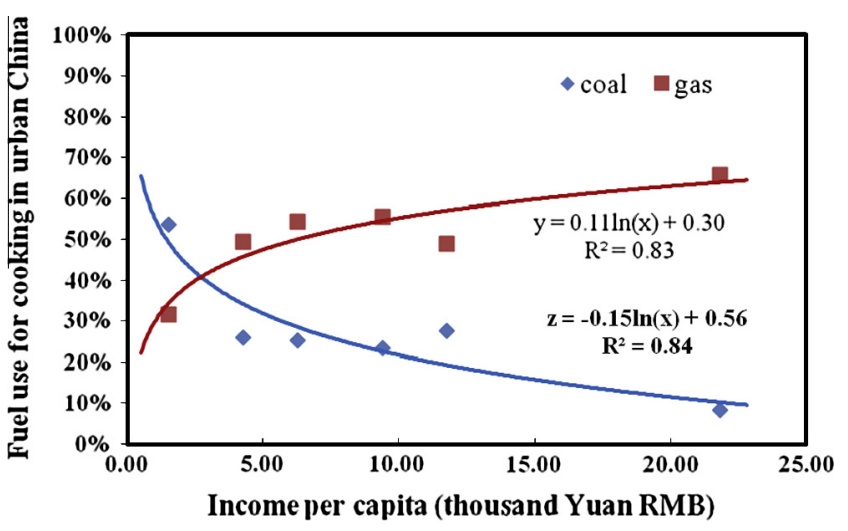

Fig. 5. Relationship between household gas/coal use and domestic income per capita in urban households in China during the last two decades.

Fig. 6 illustrates the relationship between the provincial HFU for cooking along with provincial economic level. Clearly, the proportion of gas users is positively correlated with income per capita $(p<0.05)$, while the proportion of households relying on solid fuels is negatively correlated with economic level $(p<0.05)$. The gross domestic product per capita alone explained 59\% and 35\% of the variations in the proportions of gas and SFU, respectively. The unexplained variance may be related to other factors such as the availability of solid fuels and alternative fuels that are less affected by income level.

When analyzing factors affecting the HFU pattern, we also investigated the influences of temperature and relative humidity $(\mathrm{RH})$, in addition to the income per capita (Table S3). The results showed that ambient temperature and RH significantly affected decisions about whether or not to heat households. Heating duration was positively correlated with temperature and $\mathrm{RH}$ in both rural and urban areas, but rarely depended on income level. The proportion of surveyed users relying on cleaner fuels (CLF; e.g., central heating systems or individual heating systems that use gas to heat water) was negatively correlated with ambient temperature and positively correlated with income level $\left(\mathrm{CLF}=40.9-3.18 \mathrm{~T}+\mathrm{GDP}, R^{2}=0.68, p<0.001\right)$, indicating that in the cooler areas, there were more high-income residents that preferred to use clean fuels for household heating. As expected, with the increase of GDP, the proportions of households using biomass and coals for heating would decrease. The SFU was not significantly correlated with ambient temperature, which may be explained in part by the use of solid fuels being affected by fuel abundance rather than temperature. The proportion of electricity users was positively correlated with temperature, which is coincident with the fact that in relatively hot south China, there is no central heating and most households use electricity for heating. It is noted that here we only conducted a simple analysis of factors influencing the HFU in China, and a systematic analysis of influencing factors with more data and information available should be performed in future.

It is interesting to compare the HFU pattern for cooking and that for heating, as shown in Fig. 7. We may assume that residents who use solid fuels for cooking would like to use the same fuel for household heating. Significant correlations between the fraction of SFU for heating and that for cooking were found for rural $\left(r=0.751, p=1.34 \times 10^{-6}\right)$ and urban $(r=0.353, p=0.026)$ households, with the exception of rural Ningxia, where $\sim 72 \%$ of the residents used cleaner fuels for cooking, but $95 \%$ of residents used coal for heating. Electricity/solar energy (69.5\%) and gas (28.1\%) are widely used by rural residents in Ningxia for daily cooking. It is noted that the slopes in Fig. 7 were 1.13 among households in the rural area and only 0.80 in the urban area. Although residents may occasionally burn solid fuels for daily cooking in urban areas, they mostly prefer to use clean fuels-including electricity and gas-for household heating as these fuels are available, convenient, clean, and affordable. The phenomenon can in part explain the weak correlation between the SFUs for cooking and heating in urban compared to rural areas. Furthermore, there were stronger correlations among the areas in south China compared to the northern area, in which there was a high proportion of central heating (Table S4).

\subsection{Implications and limitations}

The data collected from our extensive field surveys validate the results predicted by the WHO multilevel model. However, because the WHO model was used to predict SFU for an entire country, it may not completely account for large variations between and within countries, especially in countries with large populations and vast territories such as China. Consequently, the model may yield biased estimates of the HFU and subsequent health risk assessments. This study has provided concrete data that can inform models for use at the provincial level. These results are valuable for further research on domestic risk analysis and burden of diseases.

Previously, limited information was available on the HFU for heating in China, as well as other countries. The results of this survey can help to clarify the total consumptions and contributions of various fuel types in China to household heating, in addition to cooking. Pollutant emissions are expected to be different from the burning of fuels in the cooking and heating processes. Among the large population in China with household heating, a significant
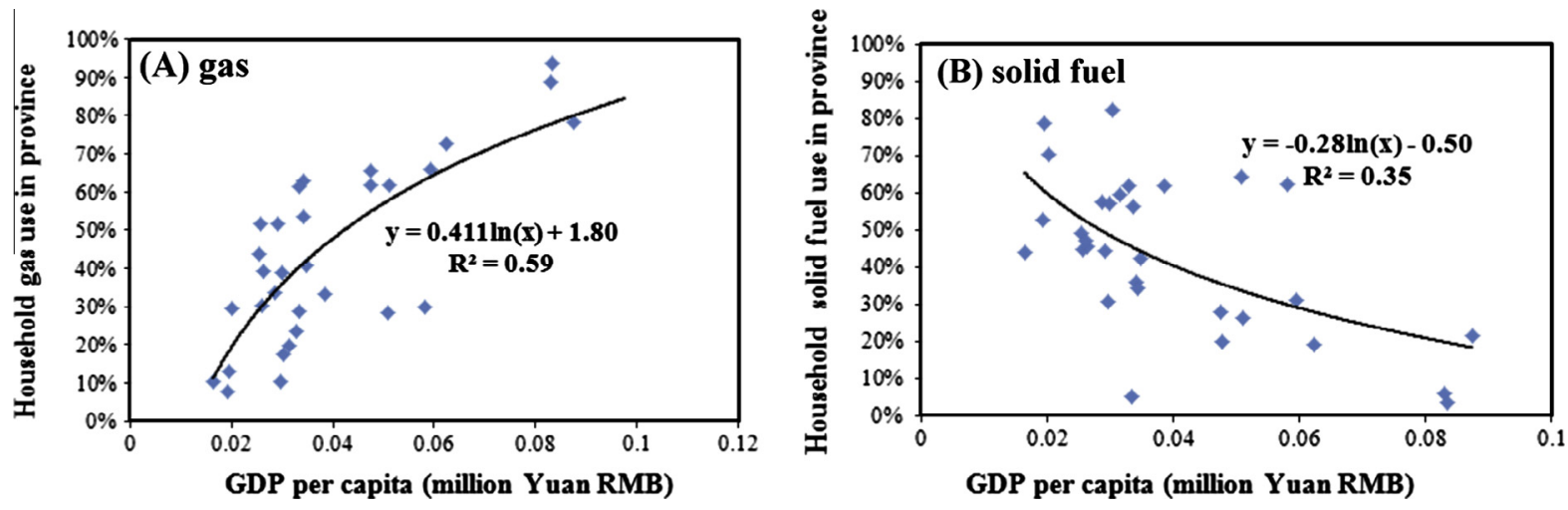

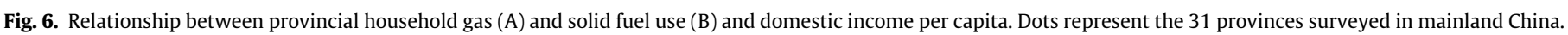



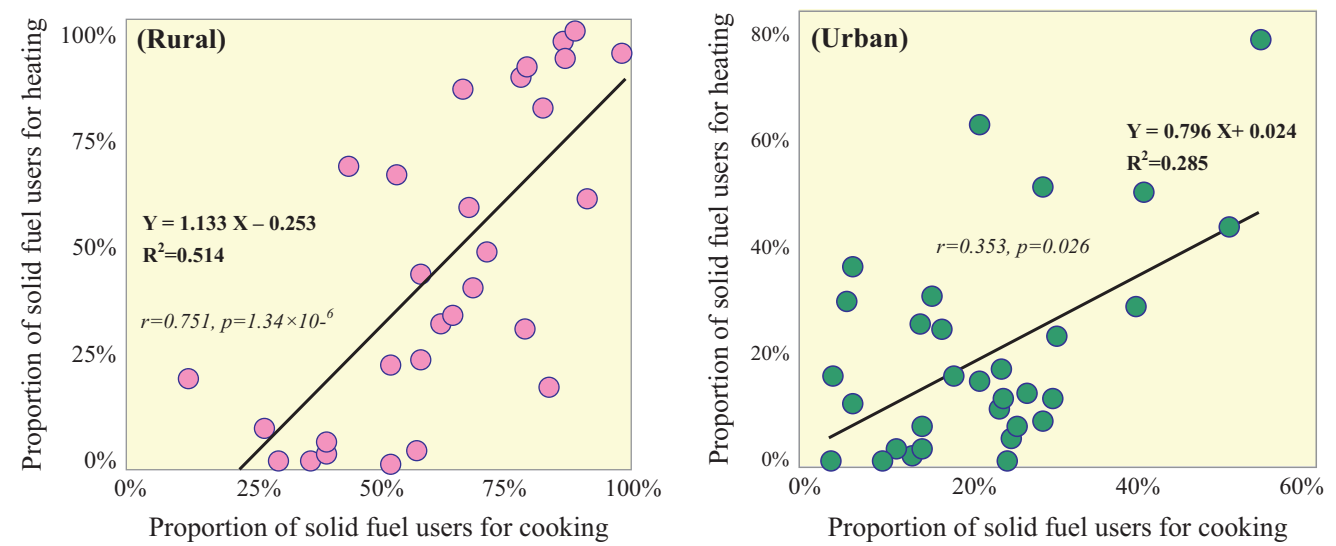

Fig. 7. Relationship between the proportion of solid fuel use (SFU) for heating and that for cooking in rural (left) and urban (right) areas in China.

number have been and may currently be exposed to dangerous pollutants, particularly during the cold season.

One limitation of the this study is that although most households used more than one type of fuel for cooking and heating, the present survey recorded only the main type of fuel used by each household. Therefore, considerable bias exists in the current reported user population percentages; since those who primarily use cleaner fuels are thought to be less likely to use solid fuels, while more rural residents use cleaner fuels such as gas and electricity in their daily lives, the percentage of the population using cleaner fuels was likely underestimated. It should also be noted that the models developed for use at the provincial level are robust, as only income, temperature and relative humidity were considered, and many other factors like accessibility of fuels, awareness and perception, fuel and stove market development, policy and financial supports etc. may affect the fuel use behavior. More studies are required to improve and validate the results before they can be generalized.

\section{Conclusions}

HFU is one of the indices used in the Millennium Development Goal indicator. In this study, we investigated the HFU patterns for cooking and heating in China, to validate the WHO model at the national scale and inform local evaluation models at the provincial level. The extensive field surveys provided firsthand data for the HFU analysis. In the year $2012,44.8 \%, 32.1 \%, 11.7 \%$, and $11.3 \%$ of Chinese households nationwide relied on gas, biomass, electricity, and coal for cooking, respectively. The patterns varied among the provinces, and differed between rural and urban areas. In rural households, solid fuels were the predominant fuel used for cooking, while in urban households, cleaner fuels were the major fuel used for cooking. During the last two decades, there was an obvious increase in non-SFU in China in both rural and urban households. With regard to the HFU for heating, $\sim 10.3 \%$ of households used a central heating system during the cold season. The proportions of households using coal, electricity and biomass for heating were $16.7 \%, 15.6 \%$ and $12.8 \%$, respectively. The heating HFU patterns differed between rural and urban households. Rural households most commonly burned traditional solid fuels, while urban residents used mainly electricity and central heating.

The HFU was affected by economic/income level. In general, there was a negative correlation between income level and the SFU proportion. The survey provided valuable firsthand data about HFU for cooking and heating in China. To some extent, it validated WHO estimates at the national level, and developed informative models for use at the provincial level. If these are confirmed with additional data, they may be used in future studies on household air pollution and the domestic burden of diseases.

\section{Appendix A. Supplementary material}

The HFU data for cooking in China from 1996 to 2012, numbers of people using different fuels in 2012, factors influencing HFU, and the relationship between the HFU for cooking and heating are available in the appendix free of charge via the Internet. Supplementary data associated with this article can be found, in the online version, at http://dx.doi.org/10.1016/j.apenergy.2014. 09.066 .

\section{References}

[1] Smith KR, Samet JM, Romieu I, Bruce N. Indoor air pollution in developing countries and acute lower respiratory infections in children. Thorax 2000;55:518-32.

[2] Pope DP, Mishra V, Thompson L, Siddiqui AR, Rehfuess EA, Weber M, et al. Risk of low birth weight and stillbirth associated with indoor air pollution from solid fuel use in developing countries. Epidemiol Rev 2010;32:70-81.

[3] Bruce NP-PR, Albalak R. Indoor Air Pollution in Developing Countries: A Major Environmental and Public Health Challenge. World Health Organization; 2000. p. 1078-92.

[4] Bonjour S, Adair-Rohani H, Wolf J, Bruce NG, Mehta S, Pruss-Ustun A, et al. Solid Fuel Use for Household Cooking: Country and Regional Estimates for 1980-2010. Environ Health Perspect 2013;121:784-90.

[5] Smith KR. Indoor air pollution in developing countries: recommendations for research. Indoor Air 2002:12:198-207.

[6] Shen GF, Xue M, Chen Y, Yang C, Li W, Shen H, et al. Comparison of carbonaceous particulate matter emission factors among different solid fuels burned in residential stoves. Atmoc Environ 2014;89:337-45.

[7] Hosgoodiii HD, Chapman RS, He X, Hu W, Tian L, Liu LZ, et al. History of lung disease and risk of lung cancer in a population with high household fuel combustion exposures in rural China. Lung Cancer 2013;81:343-6.

[8] Lim SS, Vos T, Flaxman AD, Danaei G, Shibuya K, Adair-Rohani H, et al. A comparative risk assessment of burden of disease and injury attributable to 67 risk factors and risk factor clusters in 21 regions, 1990-2010: a systematic analysis for the Global Burden of Disease Study 2010. Lancet 2012:380:2224-60.

[9] Roy A, Chapman RS, Hu W, Wei F, Liu X, Zhang J. Indoor air pollution and lung function growth among children in four Chinese cities. Indoor Air 2012:22:3-11.

[10] Reid BC, Ghazarian AA, DeMarini DM, Sapkota A, Jack D, Lan Q, et al. Research opportunities for cancer associated with indoor air pollution from solid-fuel combustion. Environ Health Perspect 2012;120:1495-8.

[11] Rehfuess E, Mehta S, Pruss-Ustun A. Assessing household solid fuel use: multiple implications for the Millennium Development Goals. Environ Health Perspect 2006;114:373-8.

[12] Nandasena $S$, Wickremasinghe AR, Sathiakumar N. Biomass fuel use for cooking in Sri Lanka: analysis of data from national demographic health surveys. Am J Ind Med 2012;55:1122-8.

[13] Galea KS, Hurley JF, Cowie H, Shafrir AL, Sanchez Jimenez A, Semple S, et al. Using PM2.5 concentrations to estimate the health burden from solid fue combustion, with application to Irish and Scottish homes. Environ Health 2013;19:12-50. Doi:10.1186/1476-069x-12-50. 
[14] Shen G, Zhang Y, Wei S, Chen Y, Yang C, Lin P, et al. Indoor/outdoor pollution level and personal inhalation exposure of polycyclic aromatic hydrocarbons through biomass fuelled cooking. Air Qual Atmos Health 2014. http:/ dx.doi.org/10.1007/s11869-014-0262-y.

[15] Duan X, Wang B, Zhao X, Shen G, Xia Z, Huang N, et al. Personal inhalation exposure to polycyclic aromatic hydrocarbons in urban and rural residents in a typical northern city in China. Indoor Air 2014. http://dx.doi.org/10.1111 ina.12099.

[16] Chang J, Leung DY, Wu CZ, Yuan ZH. A review on the energy production consumption and prospect of renewable energy in China. Renew Sustain Energy Rev 2003;7:453-68.

[17] Shen GF, Xue M. Comparison of carbon monoxide and particulate matte emissions from residential burnings of pelletized biofuels and traditional solid fuels. Energy Fuels 2014;28:3933-9.
[18] Zhang J, Smith KR. Household air pollution from coal and biomass fuels in China: measurements, health impacts and interventions. Environ Health Perspect 2007;115:848-55

[19] Shen G, Yang Y, Wang W, Tao S, Zhu C, Min Y, et al. Emission factors of particulate matter and elemental carbon for crop residues and coals burned in typical household stoves in China. Environ Sci Technol 2010;44:7157-62.

[20] Shen G, Wang W, Yang Y, Ding J, Xue M, Min Y, et al. Emissions of PAHs from indoor crop residue burning in a typical rural stove: emission factors, size distributions and gas-particle partitioning. Environ Sci Technol 2011;45:1206-12.

[21] Venkataramani AS, Fried BJ. Effect of worldwide oil price fluctuations on biomass fuel use and child respiratory health: evidence from Guatemala. Am J Public Health 2011;101:1668-74. 